TITLE:

\title{
EXPERIMENTAL STUDIES ON THE PRODUCTION AND PREVENTION OF CEREBRAL INFARCTION IN DOGS(Abstract_要旨 )
}

\section{$\operatorname{AUTHOR}(\mathrm{S}):$}

Handa, Joji

\section{CITATION:}

Handa, Joji. EXPERIMENTAL STUDIES ON THE PRODUCTION AND PREVENTION OF CEREBRAL INFARCTION IN DOGS. 京都大学, 1966, 医学博士

ISSUE DATE:

1966-06-21

URL:

http://hdl.handle.net/2433/211905

RIGHT: 


\section{【152】}

氏 名

学位. 種 類

学位. 記 番号

学位授与の日付

学位授与の要件
学位論交題目

半田讓うこ

医学 博士

論 医 博 第 301 号

昭 和 41 年 6 月 21 日

学位規則第 5 条第 2 項該 当

EXPERIMENTAL STUDIES ON THE PRODUCTION AND PREVENTION OF CEREBRAL INFARCTION IN DOGS

(犬の脳軟化の作成ならびに予防に関する実験的研究)

論文調査委員教辛授查半田肇 教授木村忠司教授本庄一夫

\section{論 文内 容 の 要 旨}

実験動物（犬）では脳動脈副血行路が高度に発達しているため, 脳軟化を適確に作成することが困難 で,したがって治療効果の実験的検定が難しい。

開頭後直接に脳動脈を単独または二, 三同時に閉塞しても病巣発生率は低く, 病巣の大きさ, 部位, 出 血の程度その他の性状す不定である。

頸部頸動脈内に各種異物を注入する方法は高度に高軟化を発生させるが, 術後早期の死亡率が高く, 病 巣の性状む不定で治療効果の検定には適当でない。また, 頸部頸動脈および椎骨動脈の閉塞のみでは脑軟 化を作成することはできない。

あらかじ女開頭後後交通動脈と前大脳動脈の起始部を閉塞し, Willis 氏動脈輪を介する副血行路を制 限した後, 頸部頸動脈に血栓を作成し, 或いは頚動脈内に凝血片その他の異物を注入することにより, 高 頻度に脳軟化巣を作成するととができた。しかす動物の死亡率は低く, 病巣は中大脳動脈領域に限定さ れ, 大きさ, 形状捄よび病巣内出血の程度もほぼ均等であり, 治療勃果の実験的検定に適している。

この方法を用いて, Plasmin による血栓溶解療法の効果を検討した。頸動脈内凝血片注入, または頸動 眽血栓作成の直前より Streptokinase, Streptokinase- 賦活人血漿による線維素溶解療法を開始すること により，犬の実験的脳軟化の発生を防止することができた。

一方，血栓の溶解をおこすに足る Plasmin 活性のあとでは高度の凝血能低下がみられる。したがって 線維素溶解療法が既存の軟化巣内への出血を誘発, 増強するととがないかを㭘討した。頸動脈内に炭素塊 または Fibrin 塊を注入して作成した新鮮な（48時間以内）脳軟化巣に対しては，全く凝血を形成し得な いほざ高度の線維素溶解能を維持しても, 病巣の拡大または出血增強の傾向は肉眼的にも組織学的にもみ とめられなかった。 


\section{論文審査の結果の要旨}

実験動物（犬）では一定の部位に大きさ，性状も一定した脳軟化巣を適確に作成することは困難で，治 療効果の実験的検定もむずかしい。従来の力法は脳動脈の単独または二, 三同時閉塞法, 頸部動脈内黑物 注入法または頸部頸動脈および椎骨動脈閉塞法などであるがいずれす適当でない。

あらかじめ開頭後後交通動脈と前大脳動脈の起始部を閉塞し，Willis 動脈輸を介する副血行路を制限 した後，頸部頸動脈に血栓を作成あるいは頸動脈内に凝血片その他の異物を注入するととにより死亡率は 低く, 中大脳動脈の領域に限定され，大きさ，形状抢よび病巣内出血の程度もほぼ均等な軟化巣を高率に 作成し得た。さらに Plasmin による血栓溶解療法の効果を検討した結果, 頸動脈内凝血片注入，または 頸動脈血栓作成の直前より Streptokinase, Streptokinase- 䟼活人血漿による線維素溶解療法を開始する ことにより，実験的脳軟化発生を防止し得た。一方，血栓の溶解をおこすに足る Plasmin 活性のもとで の線維素溶解療法の既存の軟化单内への出血の誘発, 増強の有無を48時間以内の新鮮な脳軟化巣について 検討した結果, 全く凝血を形成し得ないほど高度の線維素溶解能を維持しても病巣の拡大または出血増強 の傾向は肉眼的にも組織学的に屯認められなかった。

本論文は学術上有益にして医学博士の学位論文として侕值あるものと認定与る。 